Jurnal Pemberdayaan: Publikasi Hasil Pengabdian kepada Masyarakat

Vol. 4, No. 3, Desember 2020, Hal. 329-338

ISSN: 2580-2569; e-ISSN: 2656-0542

DOI: https://doi.org/10.12928/jp.v4i3.2802

\title{
Pelatihan Hardiness Anggota Karang Taruna Sedya Bhakti untuk Pengembangan Desa Wisata Edukasi
}

\author{
Hadi Suyono $^{1}$, Muhammad Nur Syuhada ${ }^{1}$, Sumaryanto $^{2}$ \\ Fakultas Psikologi, Universitas Ahmad Dahlan, Jl. Kapas No.9, Semaki, Kec. Umbulharjo, Kota \\ Yogyakarta, Daerah Istimewa Yogyakarta $55166^{1}$ \\ Fakultas Ekonomi dan Bisnis, Universitas Ahmad Dahlan, Jl. Kapas No.9, Semaki, Kec. Umbulharjo, \\ Kota Yogyakarta, Daerah Istimewa Yogyakarta 55166 \\ Email: hadi.suyono@psy.uad.ac.id
}

\begin{abstract}
ABSTRAK
Pelatihan merupakan tindakan efektif membangun kepribadian hardiness pada anggota karang taruna Sedya Bhakti. Tujuan dari program pelatihan ini adalah menumbuhkan pribadi anggota Karang Taruna Sedya Bhakti yang tangguh dalam rangka mengembangkan desa wisata edukasi. Metode yang digunakan merupakan pelatihan untuk meningkatkan hardiness. Caranya adalah melatih peserta mampu mengelola stres secara efektif, melatih kemampuan pemecahan masalah dan berfikir secara kreatif sehingga dapat membentuk kepribadian hardiness. Dalam pelatihan ini ada 15 anggota karang taruna Sedya Bhakti yang berpartisipasi dengan rentang usia 20 hingga 25 tahun. Jenjang pendidikan anggota karang taruna Sekolah Menengah Atas dan Strata 1. Hasil dari pelatihan ini diolah menggunakan analisa komparasi ujit-T dengan membandingkan tingkat hardines peserta sebelum dan sesudah pelatihan. Hasil yang diperoleh dengan nilai t sebesar -3,780 yang berarti terjadi peningkatan hardiness perserta setelah mengikuti kegiatan. Adanya peningkatan hardiness anggota karang taruna Sedya Bhakti dapat sebagai bekal utama menjalankan program pengembangan desa wisata edukasi secara mandiri.
\end{abstract}

Kata kunci: Pelatihan, Hardiness, Angota Karang taruna

\begin{abstract}
Training is one of the most powerful methods to develop practical skills. The purpose of this training program is to cultivate strong members of the Sedya Bhakti Youth Organization in order to develop educational tourism villages. This training method uses training techniques to increase hardiness, namely by training participants to be able to manage stress effectively, practice problem solving skills and think creatively. In this training, there were 15 people from the Youth Organization who participated, ranging in age from 20 to 25 years and with an average education at the high school to S1 levels. The results of this training were processed using the T-test comparative analysis between the hardines levels of the participants before and after the training. The results obtained with a t value of $-3,780$, which means an increase in the hardiness of the participants after participating in the activity. With an increase in the hardiness of the participants, they will be able to help participants in carrying out the educational tourism village development program independently
\end{abstract}

Keywords: Training, Hardiness, Karang Taruna members

\section{PENDAHULUAN}

Salah satu kelompok penduduk Indonesia yang memiliki jumlah paling banyak adalah masyarakat yang berada dalam kategori generasi millenial. Karakteristik yang biasa muncul dari kelompok millenial ini adalah kecenderungan dalam bersikap seperti idealisme yang tinggi, fleksibel, menginginkan sesuatu yang mudah dan lebih berorientasi pada penggunakan teknologi digital (Gunawan, 2020; Damai, Waluyo \& Mundayat 2019; Anwar, 2018; 
Mandailing, Wardi, Kusumawadi, Ulfaturahmah \& Zohri, 2019). Berdasarkan komposisi jumlah angkatan kerja yang didominasi generasi milenial tersebut memerlukan perhatian besar agar menjadi dinamisator dalam pertumbuhan ekonomi. Harapan ini dapat tercapai apabila generasi milenial memiliki kemampuan sumber daya manusia unggul sehingga mampu berkompetisi di era revolusi industri 4.0. Peluang yang bisa diraih oleh generasi milenial dalam era tersebut adalah menekuni usaha dalam bidang ekonomi kreatif (Meilinda, Lustiadi \& Hermawan, 2019).

Realitas menunjukkan bahwa generasi milenial tidak banyak memanfaatkan kesempatan mengelola sektor ekonomi kreatif. Ketidakmampuan millenial dalam memanfaatkan peluang yang ada dalam ekonomi kreatif ini mengakibatkan meningkatnya pengangguran (Handayani, 2019). Berdasarkan data yang dirilis oleh Badan Pusat Statistik tahun 2020 mencatat bahwa terjadi kenaikan tingkat pengangguran pada angkatan kerja atau usia kerja produktif dari bulan Februari tahun 2019 ke Februari tahun 2020 dengan pergerakan dari 6,82 juta jiwa naik ke 6,88 juta jiwa. Penggangguran yang bersumber dari tenaga kerja muda yang termasuk tinggi tersebut dapat disebabkan kurangnya kesiapan dan kemampuan dalam mengatasi tantangan pekerjaan yang ada sehingga dapat berdampak pada kemampuannya yang tidak memenuhi tuntutan memasuki pola ekonomi yang semakin moderen (Bali, 2019; Munarsih, 2002).

Problem kurangnya kesiapan secara internal ini juga dialami oleh anggota Karang Taruna Sedya Bhakti. Padahal Karang Taruna sendiri merupakan wadah pengembangan generasi muda yang tumbuh atas dasar kesadaran dan rasa tanggung jawab sosial dari, oleh dan untuk masyarakat khususnya generasi muda di wilayah Desa / Kelurahan atau komunitas sosial sederajat, yang terutama bergerak dibidang kesejahteraan sosial. Adapun permasalahan yang menjadi penghambat karang taruna saat ini adalah persoalan prioritas mitra berkenaan dengan peluang yang terbatas untuk mendapatkan peluang kerja di sektor formal karena kualitas sumber daya manusia rendah. Sebenarnya masih terbuka peluang bagi anggota karang taruna untuk memasuki dunia kerja dengan cara membangun usaha bidang ekonomi kreatif. Realitasnya gagasan tersebut tidak berjalan karena minimnya kemampuan psikologis berupa soft skills dan hard skills yang berkaitan dengan keterampilan berwirausaha.

Secara ideal, organisasi sosial kepemudaan Karang Taruna seharusnya menjadi wadah pembinaan dan pengembangan serta pemberdayaan dalam upaya mengembangkan kegiatan ekonomis produktif. Pengembangan dapat dilakukan dengan pendayagunaan semua potensi yang tersedia dilingkungan baik sumber daya manusia maupun sumber daya alam yang telah ada (Mudofir, 2019; Widyastuti, 2019; Pranoto, 2019; Wadu, 2019; Mahendaringrarty, 2019). Berdasarkan kondisi yang ditemukan pada Karang Taruna Sedya Bhakti merupakan wilayah terpencil memiliki topografi pegunungan berada di Desa Sriharjo, Kecamatan Imogiri, Kabupaten Bantul. Karang taruna Sedya Bakti memiliki anggota 459 orang yang pada umumnya merupakan generasi milenial. Sebagian besar dari anggota, setelah menamatkan sekolah lanjutan atas tidak melanjutkan ke perguruan tinggi. Adapun masalah utama yang dihadapi oleh karang taruna Sedya Bhakti saat ini adalah dengan pendidikan rendah mengakibatkan kualitas sumber daya yang ada menjadi tidak kompetitif. Hal tersebut menjadikan anggota Karang Taruna Sedya Bhakti tidak mendapat pekerjaan di sektor formal. Kemudian minimnya keterampilan dan pengetahuan mengenai pola manajemen bisnis yang tepat, sehingga mengakibatkan strategi wirausaha yang di usung oleh karang taruna Sedya Bhakti masih belum efektif.

Gagalnya menekuni bisnis dalam bidang ekonomi kreatif bersumber pada lemahnya kepribadian hardiness. Padahal dalam berwirausaha diperlukan adanya keyakinan diri dan kemampuan untuk bertahan serta mampu menghadapi kondisi yang tidak pasti dalam menjalankan bisnis (Wisudawati, 2017; Eunike, 2019; Juniarly, 2020). Lemahnya kepribadian hardiness pada seseorang juga akan berdampak pada penurunan daya juang dalam melanjutkan 
aktivitas yang telah di rencanakan atau mulai dikerjakan karena banyaknya pikiran negatif dan asumsi-asumsi yang menghalangi realisasi dari rencana atau kegiatan (Tesya, 2020)

Problem berkaitan dengan lemahnya kepribadian hardiness pada anggota karang taruna adalah masih memiliki keyakinan normatif memandang lapangan pekerjaan serta anggota karang taruna yang umurnya realif masih muda tidak tahan terhadap hambatan dan tantangan. Proses psikologis ini menjadikan anggota karang taruna tidak melanjutkan usaha karena menghadapi berbagai masalah saat mengelola usaha yakni desa wisata edukasi. Disamping itu para anggota karang taruna masih belum sepenuhnya yakin dan optimis terhadap kemajuan program pengembangan desa yang telah dirancang serta masih banyaknya beberapa aspek penting dalam pengelolaan dan pengembangan desa yang belum diketahui dan dipahami dengan baik oleh karang taruna.

Berdasarkan permasalahan di atas diperlukan pelatihan untuk membentuk ketangguhan diri atau daya juang anggota karang taruna agar mampu secara konsisten bertahan dalam mengelola bisnis ekononmi kreatif desa wisata edukasi. Pelatihan kepribadian hardiness penting diterapkan pada anggota karang taruna Sedya Bhakti karena memuat kemampuan bertahan, mampu menanggulangi tekanan yang dihadapi secara stabil, dan dapat mengatasi tekanan yang diterima secara positif (Anggraeni, 2014; Sufarita, 2019). Hal ini bisa terbentuk dalam kepribadian seseorang karena di dalamnya ada 3 aspek yang saling terkait, yaitu komitmen, kontrol dan tantangan (Kobasa dalam Mund, 2016) . Komitmen adalah sikap seseorang mengenai tujuan dan partisipasi dalam suatu kejadian serta kegiatan yang penting dalam hidup. Komitmen sendiri bagi karang taruna berguna sebagai penguat agar usaha yang dikerahkan dalam pembangunan desa dapat dipertahankan secara konsisten. Aspek kontrol adalah keyakinan seseorang untuk dapat memengaruhi setiap kejadian dalam hidup sesuai dengan tujuan atau motif yang dimilikinya. Kontrol dapat digunakan sebagai alat evaluasi baik secara mandiri maupun kolektif bersama-sama untuk memperhatikan kualitas kerja dalam proses pembangunan desa. Selanjutnya aspek tantangan merupakan kecenderungan orang untuk memandang perubahan sebagai suatu keuntungan dan peluang untuk mengembangkan diri (Amirudin, 2014; Rosulin, 2016; Dani, 2019). Nilai dari suatu tantangan dapat memberikan kontribusi kepada pola pikir karang taruna agar mampu memikirkan strategi pengembangan yang lebih menarik dan memiliki daya jual.

Upaya membentuk kepribadian karang taruna yang tangguh dapat dilakukan dengan berbagai cara. Salah satu cara yang dilakukan dengan pelatihan. Pelatihan dapat dipakai sebagai metode karena bermanfaat untuk meningkatkan keterampilan yang dinginkan yakni dalam hal ini hardiness secara langsung dan mampu menciptakan nilai pengalaman yang aplikatif serta lebih mudah dicerna oleh peserta pelatihan (Marlina, 2013; Pasali, 2015; Nila, 2016). Hardiness sebagai betuk kepribadian yang bersifat aplikatif sangat cocok di sampaikan melalui pendekatan yang praktis salah satunya yakni melalui partisipasi aktif dalam proses pelatihan keterampilan.

Pelatihan yang dirancang khusus untuk membantu meningkatkan hardiness peserta secara praktik ditujukan untuk membantu peserta lebih memahami bagaimana konsep dari hardiness dan cara menerapkan secara efektif didalam kehidupan sehari-hari terutama dalam kegiatan berwirausaha. Adapun materi pelatihan yang diberikan adalah mengenai cara mengelola stress, mengambil keputusan dengan efektif serta melatih cara berpikir kreatif dalam menyikapi berbagai situasi. Oleh karna itu pelatihan hardiness cocok untuk diterapkan pada karangtaruna dalam membentuk pribadi yang tangguh.

\section{METODE}

Metode yang diterapkan dalam kegiatan ini adalah pelatihan membentuk pribadi tangguh dan mampu mengatasi tekanan dalam berbagai situasi. Dalam kegiatan ini diberikan beberapa kegiatan yaitu pengukuran tingkat hardiness peserta sebelum dan sesudah pelatihan, 
penyiapan materi dan praktek melatih kepribadian hardiness yang meliputi pengenalan dan pemahaman mengenai stres dan faktor penyebabnya, cara mengatasi stres dengan teknik berpikir positif dan kreatif, serta cara efektif dalam memecahkan masalah. Adapun langkah langkah yang ditempuh dalam kegiatan pelatihan Hardiness disajikan pada Tabel 1.

Tabel 1. Metode pelaksanaan kegiatan

\begin{tabular}{|c|c|c|}
\hline No & Materi & Metode Pelaksanaan \\
\hline 1 & Pre-test Hardiness & $\begin{array}{l}\text { Pemberian angket tertulis kepada peserta untuk } \\
\text { mendapatkan tingkat hardiness yang dimiliki } \\
\text { peserta sebelum pelatihan }\end{array}$ \\
\hline \multirow[t]{5}{*}{2} & Pelatihan pengelolaan stress & $\begin{array}{l}\text { Metode indoor, praktek, game, simulasi, dan } \\
\text { role play. } \\
\text { a. Mengukur tingkat stres yang dialami } \\
\text { b. Mengidentifikasi penyebab stres } \\
\text { c. Pemberian materi mengenai definisi stres } \\
\text { dan alasan seseorang dapat mengalami } \\
\text { stress }\end{array}$ \\
\hline & & $\begin{array}{lll}\text { d. Melakukan kegiatan berpikir } & \text { positif } \\
\text { dengan menggabungkan } & \text { teknik } \\
\text { pernafasan dan kekuatan pikiran } & \end{array}$ \\
\hline & & $\begin{array}{l}\text { e. Pemberian pemahaman mengenai berpikir } \\
\text { dan bertindak positif dalam menghadapi } \\
\text { tekanan dan menyelesaikan masalah }\end{array}$ \\
\hline & & $\begin{array}{l}\text { f. Kegiatan sharing bersama mengenai } \\
\text { pengalaman cara mengatasi tekanan }\end{array}$ \\
\hline & & $\begin{array}{l}\text { g. Pemberian pemahaman mengenai konsep } \\
\text { hardiness dan aspek-aspek yang terdapat } \\
\text { didalam hardiness }\end{array}$ \\
\hline
\end{tabular}

$3 \quad$ Pemecahan masalah role play.

a. Identifikasi masalah yang sedang dihadapi peserta

b. Melakukan simulasi cara memecahkan masalah

c. Memberikan pemahaman mengenai karakteristik dari suatu masalah

d. Memberikan pemahaman mengenai tahap pemecahan masalah yang efektif

$4 \quad$ Berpikir kreatif

Metode indoor, praktek, game, simulasi, dan role play.

a. Melakukan permaian untuk menguji penerapan kreatifitas peserta

b. Memberikan pemahaman mengenai kreatifitas dan berpikir kreatif

c. Memberikan pemahaman mengenai ciriciri orang yang berpikir kreatif

d. Memberikan pemahamana mengenai proses kreatif 


\begin{tabular}{lll}
\hline 5 Post-test Hardiness & $\begin{array}{l}\text { Pemberian angket tertulis kepada peserta untuk } \\
\text { mendapatkan tingkat hardiness yang dimiliki } \\
\text { peserta setelah pelatihan }\end{array}$ \\
\hline
\end{tabular}

Pelatihan ini dilakukan di Desa Sriharjo, Kecamatan Imogiri, Kabupaten Bantul, Daerah Istimewa Yogyakarta. Adapun peserta yang mengikuti pelatihan ini adalah karang taruna dengan rentan gusia 20 hingga 25 tahun serta dengan rata-rata tingkat pendidikan mulai dari Sekolah Menengah Atas dan Strata 1. Hasil dari pelatihan hardiness ini diukur dengan analisa statistik membandingkan tingkat hardiness peserta sebelum dan sesudah pelatihan diberikan dengan menggunakan uji-T melalui program SPSS 23.

Proses kegiatan pelatihan dilaksanakan di masa pandemi sehingga tetap memperhatikan protokol kesehatan pencegahan Covid 19. Protokol kesehatan yang dilakukan adalah membatasi jumlah peserta, menggunakan masker, jaga jarak, dan disedikan peralatan cuci tangan selama proses kegiatan. Adapun kegiatan dari pengabdian masyarakat selama pelatihan berlangsung meliputi:

\section{Sosialisasi kegiatan}

Pelatihan hardiness dilaksanakan sesuai perencanaan dan dilakukan secara bertahap. Sebelum dilaksanakan program pelatihan telah dilakukan sosialisasi bertujuan mengenalkan rencana kegiatan pelatihan kepada mitra dan pihak terkait. Pelaksanaan sosialisasi tersebut dilaksanakan bersama pemerintah setempat, pengurus karang taruna, dan tokoh masyarakat. Kegiatan sosialisasi dilaksanakan secara informal dan santai, dengan menyampaikan susunan kegiatan pelatihan dan workshop serta sasaran yang akan dicapai dari kegiatan tersebut. Berikut gambar saat sosialiasi kegiatan ada pada Gambar 1.

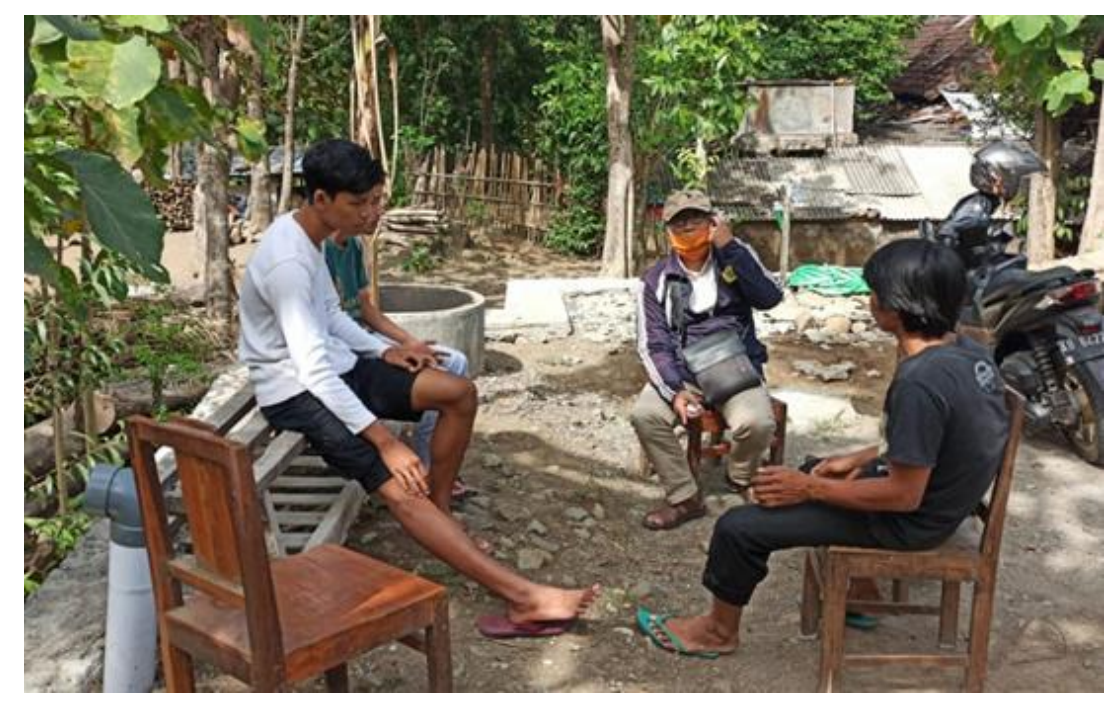

Gambar 1. Kegiatan Sosialisasi

\section{Pre-Test Hardiness}

Pengukuran tingkat hardiness peserta dilakukan sebelum pelatihan dilakukan. Pengukuran dilakukan dengan memberikan angket tertulis yang harus diisi oleh tiap peserta yang berisikan 40 aitem pernyataan yang disusun berdasarkan konstrak dari aspek-aspek pembangun hardiness yang dikemukakan oleh Kobasa (Mund, 2016) yakni aspek kontrol, komitmen, dan tantangan. 


\section{Teknik Pengelolaan Stres}

Rangkaian pelatihan hardiness dikemas dengan model kegiatan interaktif dengan bentuk permainan-permainan yang berkaitan materi. Materi sesi pertama mengenai kepribadian hardiness dimana trainer memberikan pemahaman kepada peserta mengenai kepribadian hardiness serta metode berpikir dan bertindak positif untuk mengatasi stres. Kemudian, trainer mengajak peserta menganalisa permasalahan-permasalahan yang dihadapi saat ini. Dan selanjutnya peserta dalam bentuk kelompok, saling memberikan solusi atas permasalahan yang dihadapi oleh peserta lain secara bergantian. Pada akhir sesi ini trainer menyampaikan konsep teori mengenai hardiness dan aspek-aspek pembentuk dari hardiness. Pengelolaan stres diperlukan dalam membentuk kepribadian hardiness dikarenakan kemampuan seseorang untuk mampu beradaptasi dalam situasi yang sulit menjadi dasar utama untuk mampu tangguh secara konsisten dalam menyikapi berbagai situasi (Kim, Lee \& Lee, 2016). Berikut pemberian materi teknik pengelolaan stress ada pada Gambar 2.

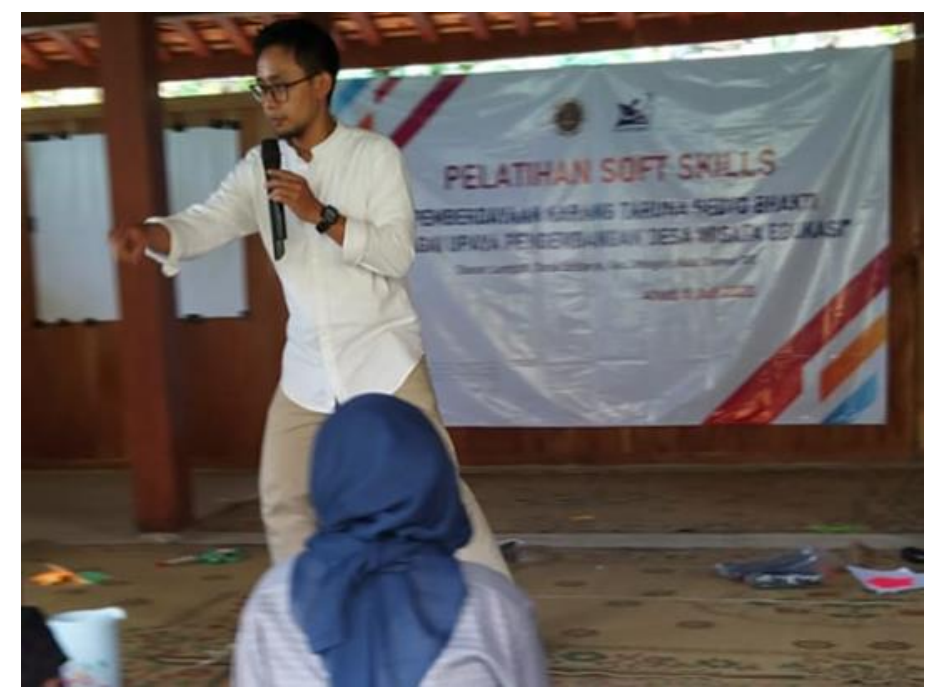

Gambar 2. Pelatihan Hardiness

\section{Teknik Pemecahan Masalah}

Materi sesi berikutnya mengenai problem solving, yang pada sesi tersebut trainer meminta peserta untuk berpartisipasi dalam sebuah aktivitas permainan untuk mengenalkan kepada peserta arti dari proses pemecahan masalah. Trainer juga menginstruksikan setiap peserta untuk mencari permasalahan apa saja yang ada di desa dalam waktu beberapa menit pada lembar latihan yang telah disediakan. Setelah peserta selesai mengerjakan latihan diminta untuk membuat kelompok, kemudian diminta untuk berdiskusi memutuskan beberapa tema permasalahan utama di desa mereka. Kemudian diakhiri dengan diskusi solusi permasalahan dan penjelasan tahapan-tahapan problem solving. Pemecahan masalah berkaitan dengan hardiness dimana seseorang akan mampu menghadapi berbagai situasi dengan adanya kapabilitas untuk mengamati, menilai serta menghasilkan solusi yang efektif dari situasi tersebut (Abdollahi, Abu Talib, Carlbring, Harvey, Yaacob \& Ismail, 2018). Berikut pemberian materi problem solving ada pada Gambar 3. 


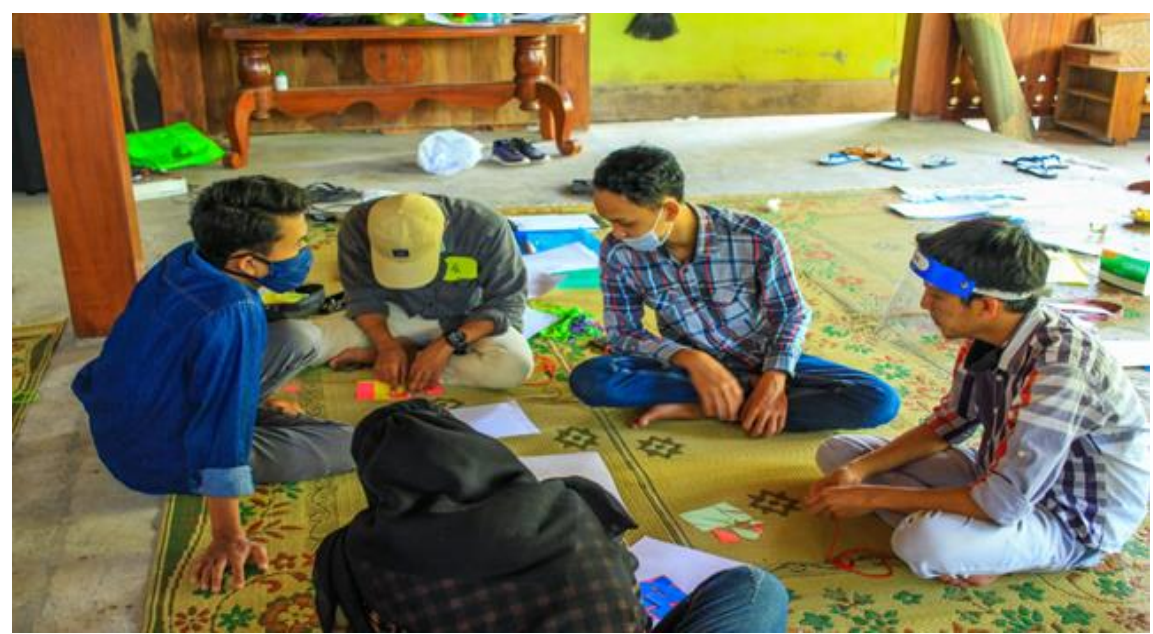

Gambar 3. Kegiatan Problem Solving

\section{Teknik Berpikir Kreatif}

Agenda selanjutnya dari pelaksanaan pelatihan hardiness adalah melatih peserta untuk mampu menerapkan cara berpikir kreatif dalam menghadapi permasalahan. Trainer mengajak peserta untuk berpartisipasi aktif mengikuti sebuah permainan dimana trainer membagikan kepada setiap peserta beberapa material untuk di rakit menjadi sesuatu yang memiliki keunikan dan kegunaan tertentu. Setelah selesai permainan trainer meminta perwakilan peserta untuk mempresentasikan. Trainer menjelaskan materi berpikir kreatif dan tahapan kreatif. Kreativitas diperlukan agar membantu dalam pembentukan solusi yang efektif dan menarik sehingga dapat diterapkan dengan cara yang lebih bervariatif namun tetap mampu memberikan solusi yang diharapkan (Nuriyani, 2018).

\section{Post-Test Hardiness}

Pengukuran tingkat hardiness peserta juga dilakukan setelah pelatihan dilakukan. Pengukuran dilakukan dengan memberikan angket tertulis yang harus diisi oleh tiap peserta yang berisikan 40 aitem pernyataan yang disusun berdasarkan konstrak dari aspek-aspek pembangun hardiness yang dikemukakan oleh Kobasa (Mund, 2016) yakni aspek kontrol, komitmen, dan tantangan.

\section{HASIL, PEMBAHASAN, DAN DAMPAK}

Hasil dari pelatihan diukur melalui perbandingan tingkat hardiness peserta sebelum dan sesudah pelatihan dengan menggunakan skala kepribadian hardiness. Adapun pengolahan data hasil perbandingan dari pelatihan dilakukan secara kuantitatif menggunakan uji statistik dengan program SPSS 23 melalui rumus uji-T. Berdasarkan hasil keseluruhan kegiatan pelatihan yang dilakukan, didapati bahwa terjadi peningkatan tingkat hardiness peserta. Hal ini dibuktikan dengan nilai pre-test dan post-test peserta naik dengan nilai mean $-16,750$, standar deviasi 12,533 dan t -3,780 dengan sig. (2-tailed) .007. Berikut hasil uji statistik menggunakan dengan uji t dapat dilihat pada Tabel 2.

Tabel 2. Mean, Std. Deviation, t, and sig.

\begin{tabular}{ccccc}
\hline $\begin{array}{c}\text { Pair 1 } \\
\text { Pretest } \\
\text { Posttest }\end{array}$ & Mean & Std. Deviation & $\mathrm{t}$ & Sig. (2-tailed) \\
\cline { 2 - 5 } & $-16,750$ & 12,533 & $-3,780$ & .007 \\
\hline
\end{tabular}


Gambar 4 menyajikan grafik peningkatan kemampuan hardiness peserta. Berdasarkan data peningkatan hardiness peserta setelah pelatihan tersebut dapat dimaknai bahwa tingkatan hardiness yang dimiliki seseorang dapat dipengaruhi oleh kapasitas dan kemampuan dalam mengelola stres. Hal ini dikarenakan semakin mampu seseorang dalam mengendalikan responnya terhadap situasi yang menekan maka akan semakin objektif pemahamannya dalam menyikapi masalah sehingga mampu bertahan (Sindik, Augustin, Lewis \& Novokmet, 2014). Disamping itu tingkatan hardiness juga dipengaruhi oleh seberapa realistis dan efektif solusi yang dapat dipikirkan dan dihasilkan seseorang untuk setiap permasalahan yang dihadapinya. Solusi yang efektif dan reliabel untuk diterapkan akan membuat seseorang menjadi lebih percaya diri untuk mengaplikasikannya dikarenakan tingkat keberhasilannya mampu diprediksi dengan baik (Abdollahi, Abu Talib, Carlbring, Harvey, Yaacob \& Ismail, 2018). Kemudian tingkatan hardiness juga dipengaruhi oleh seberapa kreatif seseorang untuk mampu menemukan solusi yang cocok dan paling membuat orang tersebut senang melakukannya. Kreatifitas menjadi modal untuk membentuk perspektif yang lebih beragam dan unik dalam menyikapi suatu persoalan maupun dalam menghasilkan pemecahan masalah, serta kreatifitas juga dapat mempengaruhi bagaimana seseorang akan menentukan sikap terhadap persoalan yang dihadapi (Wulandari, 2017).

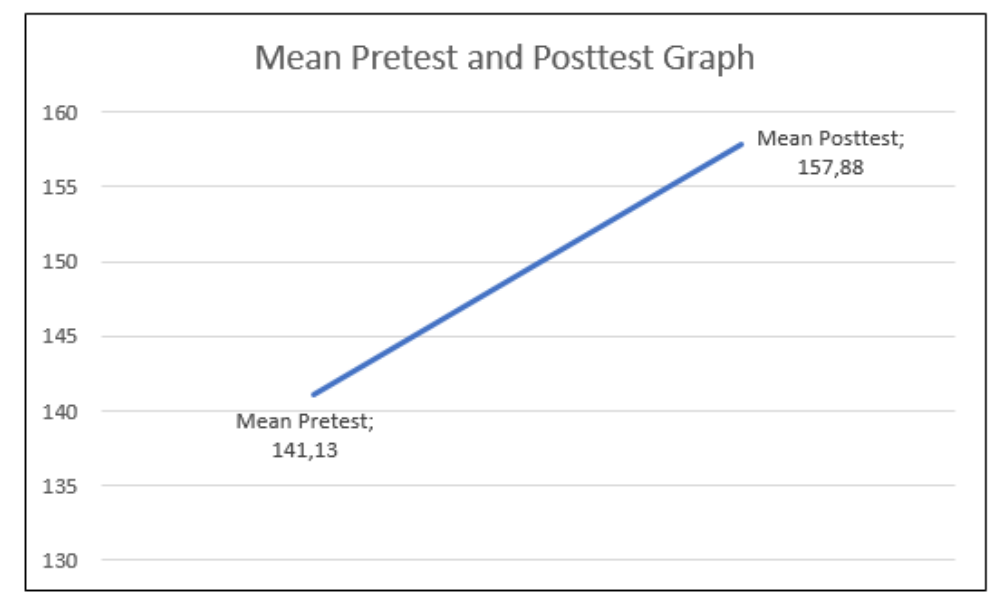

Gambar 4. Perbandingan rerata tingkat hardiness sebelum dan sesudah kegiatan

\section{SIMPULAN}

Pelatihan hardiness memberikan kontribusi kepada anggota karang taruna Sedya bhakti. Hal ini dapat dilihat dari hasil uji statistik peningkatan hardines peserta setelah pelatihan yang naik dengan nilai mean 16,750, standar deviasi 12,533 dan t -3,780 dengan sig. (2-tailed) 007 . Hal ini dapat disimpulkan bahwa metode pelatihan terbukti mampu meningkatkan hardiness peserta. Adapun manfaat yang mereka peroleh adalah peningkatan kemampuan untuk memahami dan mengelola stres serta memahami cara memecahkan masalah dengan kreatif.

\section{UCAPAN TERIMAKASIH}

Terimakasih yang sebesar-besarnya penulis ucapkan pada pihak-pihak yang telah membantu kelancaran penulisan jurnal kegiatan pelatihan ini. Penulis mengucapkan terimakasih kepada Lembaga Penelitian dan Pengabdian Masyarakat Universitas Ahmad Dahlan, Direktorat Jenderal Pendidikan Tinggi Kementerian Pendidikan dan Kebudayaan, dan Karang Taruna Sedya Bhakti yang telah mendukung pelatihan kepribadian hardiness secara maksimal sehingga dapat terlaksana dengan baik. 


\section{DAFTAR PUSTAKA}

Abdollahi, A., Abu Talib, M., Carlbring, P., Harvey, R., Yaacob, S. N., \& Ismail, Z. (2018). Problem-solving skills and perceived stress among undergraduate students: The moderating role of hardiness. Journal of Health Psychology, 23(10).

Amiruddin, J. H., \& Ambarini, T. K. (2014). Pengaruh hardiness dan coping stress terhadap tingkat stres pada kadet akademi TNI-AL. Jurnal Psikologi Industri dan Organisasi, 3(02)

Anggraeni, T. P., \& Jannah, M. (2014). Hubungan Antara Psychological Well-Being dan Kepribadian Hardiness Dengan Stres Pada Petugas Port Security. Jurnal Character, 3(2)

Anwar, H. S. (2019, July). Resilience pada Generasi Millennial dalam Berwirausaha di Kota Surabaya. In Proceeding National Conference Psikologi UMG 2018 (Vol. 1, No. 1)

Badan Pusat Statistik (2020). Keadaan Ketenagakerjaan Indonesia Februari 2020. No. 40/05/Th. XXIII, 05 Mei 2020

Bali, I. N. A. P., \& Darma, G. S. (2019). Menguji Kesiapan Pengelolaan Desa Berbasis Manajemen Modern Guna Menghadapi Era Revolusi Industri 4.0. Jurnal Manajemen Bisnis, 16(2)

Damai, D. F., Waluyo, S. D., \& Mundayat, A. A. (2020). Karakter Generasi Milenial Prekariat Di Lingkungan Ekonomi Kreatif Dalam Upaya Mendukung Ketahanan Ekonomi (Studi Kasus Kemampuan Karyawan Di Rgb Creative Digital Media). Ekonomi Pertahanan, 5(2).

Dani, R. (2019). Pengaruh hardiness dan kepribadian big five terhadap intensi berwirausaha mahasiswa UIN Jakarta. Skripsi. Fakultas Psikologi Universitas Islam Negeri Syarif Hidayatullah Jakarta.

Eunike, A., Mayangsari, M. D., \& Hidayatullah, M. S. (2020). Hubungan Antara Kematangan Vokasional Dengan Hardiness Pada Siswa Smk Negeri 1 Martapura. Kognisia prodi Psikologi FK ULM, 2(2)

Gunawan, A. (2020). Pelatihan Digital Entrepreneurship Mewujudkan Generasi Milenial Berjiwa Wirausaha Di Sekolah SMA Desa Karangasih Cikarang. Jurnal Abdimas Kartika Wijayakusuma, 1(Nomor 1), 38-45.

Handayani, A., Kuncoro, J., \& Rohmatun, R. (2019). Penelusuran Minat Karir Millennial. PLAKAT (Pelayanan Kepada Masyarakat), 1(2)

Juniarly, A., \& Arishanti, N. (2020). Hardiness, Penyesuaian Diri Dan Stres Pada Siswa Taruna. Psikoislamedia: Jurnal Psikologi, 4(2)

Kim, Y. J., Lee, H. M., \& Lee, S. Y. (2016). The Relationship between Stress, Psychological Hardiness, Social Support and Quality of Life in Insomniacs. Korean Journal of Stress Research, 24(3).

Mahendaringratry, A., \& Handaratri, A. (2019). Pelatihan Strategi Kewirausahaan Mandiri Karang Taruna Dewa Singha Kelurahan Merjosari Kota Malang. JAST: Jurnal Aplikasi Sains dan Teknologi, 3(1)

Mandiling, I. H., Wardi, F., Kusumawadi, M. A., Ulfaturrahmah, L., \& Zohri, T. (2019). Pemberdayaan Generasi Milenial Desa Ranggagata Melalui Budidaya Puyuh Berbasis Edupreneur. Jurnal Pendidikan dan Pengabdian Masyarakat, 2(2).

Marlina, Desi (2013) Rancangan dan Uji Coba Modul Pelatihan untuk Meningkatkan Hardiness pada Staff Pajak yang Bekerja di PT X dalam Rangka Resilience at Work. Masters thesis, Universitas Kristen Maranatha.

Meilinda, S. D., Lustiadi, Y., \& Hernawan, W. (2019). Millennial behavior: Sebuah pendekatan dalam perilaku kepemimpinan. Wacana Publik, 13(02).

Mudofir, I., Maftuh, M. F., \& Rahayu, T. (2019). Pelatihan Strategi Revitalisasi Karang Taruna Desa Doho, Kecamatan Dolopo, Kabupaten Madiun. DIKEMAS (Jurnal Pengabdian Kepada Masyarakat), 3(1). 
Munarsih, M., Akbar, M. F., Ariyanto, A., Ivantan, I., \& Sudarsono, A. (2020). Pelatihan Digital Marketing Dalam Meningkatkan Kompetensi Siswa Untuk Berwirausaha Pada Smk Muhammadiyah Parung-Bogor. Jurnal Pengabdian Dharma Laksana, 3(1)

Mund, P. (2016). Kobasa concept of hardiness. International research journal of engineering, IT \& scientific research, 2(1)

Nila Wisudawati, Winy (2016) Efektivitas pelatihan hardiness untuk meningkatkan motivasi berprestasi akademik siswa atlet (Studi pada sekolah $X$, Tangerang). Masters thesis, Universitas Tarumanagara.

Nuriyani, A. (2018). Hubungan antara hardiness dengan creative thinking mahasiswa prodi Pendidikan Islam Anak Usia Dini (PIAUD) Fakultas Tarbiyah dan Keguruan Universitas Islam Negeri Sunan Ampel Surabaya (Doctoral dissertation, UIN Sunan Ampel Surabaya).

Pasali, Yoas Yanri (2015) Efektifitas Pelatihan Hardiness untuk Meningkatkan Hardiness pada Karyawan PT. " $X^{\prime \prime}$ di Bandung dalam Rangka Resilience at Work. Masters thesis, Universitas Kristen Maranatha.

Pranoto, P., Jasmani, J., \& Marayasa, I. N. (2019). Pelatihan Digital Marketing Untuk Peningkatan Perekonomian Anggota Karang Taruna Al Barkah Di Kampung CicayurTangerang. Jurnal Pengabdian Dharma Laksana, 1(2)

Rosulin, R., \& Paramita, P. P. (2016). Hubungan antara hardiness dengan adaptabilitas karir pada siswa SMK kelas XII. Jurnal Psikologi Pendidikan dan Perkembangan, 5(1)

Sindik, J., Havaš Auguštin, D., Perinić Lewis, A., \& Novokmet, N. (2014). Associations among perceived stress and hardiness at nursing and criminology students. Annals of Biological research, 5(1).

Sufarita, S., Sahrani, R., \& Hastuti, R. (2019). Peranan Emotional Intelligence Dan Self Efficacy Terhadap Hardiness Pada Peserta Orientasi Persiapan Kerja. Jurnal Muara Ilmu Sosial, Humaniora, dan Seni, 3(2)

Tesya, T. (2020). Hubungan antara Hardiness dengan Motivasi Berprestasi Pada Mahasiswa yang Bekerja (Doctoral dissertation, Universitas Tarumanagara).

Wadu, L. B., Ladamay, I., \& Jama, S. R. (2019). Keterlibatan Warga Negara Dalam Pembangunan Berkelanjutan Melalui Kegiatan Karang Taruna. Jurnal Pendidikan Kewarganegaraan, $9(2)$

Widhigdo, J. C., Ahuluheluw, J. M., \& Pandjaitan, L. N. (2020). Pelatihan ketangguhan untuk meningkatkan kesejahteraan psikologis pengurus unit kegiatan mahasiswa (UKM) di Universitas Surabaya. Jurnal Psikologi Ulayat: Indonesian Journal of Indigenous Psychology.

Widyastuty, S. A. (2019). Pemberdayaan Pemuda Karang Taruna Melalui Program Remaja Peduli Lingkungan Desa Wisata Kebontunggul. Jurnal Penamas Adi Buana, 3(1)

Wisudawati, W. N., Sahrani, R., \& Hastuti, R. (2018). Efektivitas Pelatihan Ketangguhan (Hardiness) Untuk Meningkatkan Motivasi Berprestasi Akademik Siswa Atlet (Studi Pada Sekolah X di Tangerang). Provitae: Jurnal Psikologi Pendidikan, 10(2).

Wulandari, S. (2017). Hubungan antara hardiness dengan creative thinking pada mahasiswa PGMI (Doctoral dissertation, UIN Sunan Ampel Surabaya). 